\title{
PEMODELAN ANGKA HARAPAN HIDUP PROVINSI JAWA TENGAH MENGGUNAKAN ROBUST SPATIAL DURBIN MODEL
}

\author{
Maghfiroh Hadadiah Mukrom ${ }^{1}$, Hasbi Yasin², Arief Rachman Hakim ${ }^{3}$ \\ 1,2,3 Departemen Statistika FSM Universitas Diponegoro \\ email: maghfirohhadadiah98@gmail.com
}

\begin{abstract}
Spatial regression is a model us ed to determine relationship between response variables and predictor variables that gets s patial influence. If there are spatial influences on both variables, the model that will be formed is Spatial Durbin Model. One reason for the inaccuracy of the spatial regression model in predicting is the exis tence of outlier observations. Removing outliers in s patial analy sis can change the composition of s patial effects on data. One way to overcome of outliers in the spatial regression model is by using robust spatial regression. The application of $\mathrm{M}$-estimator is carried out in estimating the spatial regression parameter coefficients that are robust against outliers. The aim of this research is obtaining model of number of life expectancy in Central Java Province in 2017 that contain outliers. The results by applying M-estimator to es timating robust s patial durbin model regression parameters can accommodate the existence of outliers in the s patial regression model. This is indicated by the change in the estimating coefficient value of the robust spatial durbin model regres sion parameter which can increase adjusted $\mathrm{R}^{2}$ value becomes $93,69 \%$ and decrease MSE value becomes 0,12551 .
\end{abstract}

Keywords: Outliers, M-estimator, Spatial Durbin Model, Number of Life Expectancy.

\section{PENDAHULUAN}

Analisis regresi merupakan suatu teknik analisis statistik yang bertujuan untuk melihat hubungan antara variabel respon dan variabel prediktor sehingga mampu memprediksikan variabel respon jika variabel prediktornya diketahui. Ketika ditemukan adanya efek spasial (lokasi) pada data yang biasa disebut dengan data spasial, maka analis is regresi yang digunakan adalah regresi spasial. Pemodelan dengan menggunakan regresi spasial salah satunya adalah model SpatialDurbin Model (SDM). Model SDM adalah model regresi spasial yang menunjukkan adanya efek spasial dalam variabel respon maupun variabel prediktor ${ }^{[1]}$.

Dalam analisis data, terkadang ditemukan adanya pencilan (outlier). Adanya pencilan membuat estimasi parameter menjadi bias. Untuk menganalisis data yang terkontaminasi oleh pencilan dapat digunakan suatu metode analisis statistik yaitu regresi robust. Salah satu metode estimasi pada regresi robust adalah $M$-estimator yang merupakan metode regresi robust yang paling sederhana baik secara teoritis maupun secara komputasi $^{[4]}$. Salah satu metode yang dapat digunakan untuk deteksi pencilan pada data spasial adalah Moran's Scatterplot. Karena data yang akan digunakan adalah data spasial, maka analisis regresi robust yang digunakan adalah regresi robust spatial.

Salah satu aplikasi dari model regresi spasial yaitu pada kasus Angka Harapan Hidup (AHH). Pembentukan model regresi spasial pada penelitian ini dilakukan menggunakan software $R$ yang dapat memberikan hasil estimasi yang lebih efektif dan efisien karena tidak perlu melakukan perhitungan manual secara berkali-kali. Penelitian ini difokuskan pada pembentukan model SDM dan robust SDM dengan menggunakan software $R$ pada kasus AHH menurut kabupaten/kota di Provinsi Jawa Tengah tahun 2017.

\section{TINJAUAN PUSTAKA}

\subsection{Regresi Linier Berganda}

Regresi linier berganda merupakan model regresi yang mengandung lebih dari satu variabel prediktor ${ }^{[14]}$. Persamaan regresi linier berganda dengan $\mathrm{k}$ variabel prediktor adalah sebagai berikut: 


$$
y_{i}=\beta_{0}+\beta_{1} x_{i 1}+\beta_{2} x_{i 2}+\ldots .+\beta_{k} x_{i k}+\varepsilon_{i}
$$

\subsection{Matriks Pembobot Spasial}

Matriks pembobot spasial digunakan untuk menentukan bobot antar lokasi yang diamati berdasarkan hubungan ketetanggaan antar lokasi. Ketetanggaan dapat didefinis ikan dalam beberapa cara, yaitu ${ }^{[17]}$ :

1. Rook Contiguity (Persinggungan Sisi)

Daerah pengamatannya ditentukan berdasarkan sisi-sisi yang saling bersinggungan dan sudut tidak diperhitungkan.

2. Bishop Contiguity (Persinggungan Sudut)

Daerah pengamatannya ditentukan berdasarkan sudut-sudut yang saling bersinggungan dan sisi tidak diperhitungkan.

3. Queen Contiguity (Persinggungan Sisi-Sudut)

Daerah pengamatannya ditentukan berdasarkan sisi-sisi yang saling bersinggungan dan sudut juga diperhitungkan.

\subsection{Uji Moran's I}

Untuk mengetahui apakah ada autokorelasi spasial antar lokasi dapat dilakukan uji autokorelasi spasial dengan menggunakan uji Moran 's I ${ }^{[9]}$, dengan hipotesis sebagai berikut: $\mathrm{H}_{0}$ : Tidak ada autokorelasi spasial antar lokasi

$\mathrm{H}_{1}$ : Ada autokorelasi spasial antar lokasi

Statistik Uji: $Z_{\text {hitung }}=\frac{I-E(I)}{\sqrt{\operatorname{var}(I)}}$

dengan:

$$
\begin{array}{ll}
I=\frac{n \sum_{i=1}^{n} \sum_{j=1}^{n} w_{i j} c_{i j}}{\sum_{i=1}^{n} \sum_{j=1}^{n} w_{i j} \sum_{i=1}^{n}\left(x_{i}-\bar{x}\right)^{2}} & S_{0}=\sum_{i=1}^{n} \sum_{j=1}^{n} w_{i j} \\
E(I)=I_{0}=-\frac{1}{n-1} & S_{1}=\frac{1}{2} \sum_{i \neq j}^{n}\left(w_{i j}+w_{j i}\right)^{2} \\
c_{i j}=\left(x_{i}-\bar{x}\right)\left(x_{j}-\bar{x}\right) & S_{2}=\sum_{i \neq j}^{n}\left(w_{i 0}+w_{0 i}\right)^{2} \\
\operatorname{var}(I)=\frac{n^{2} S_{1}-n S_{2}+3 S_{0}^{2}}{\left(n^{2}-1\right) S_{0}^{2}}-[E(I)]^{2} & w_{i 0}=\sum_{i=1}^{n} w_{i j} ; w_{0 i}=\sum_{j=1}^{n} w_{j i}
\end{array}
$$

Keputusan: $\mathrm{H}_{0}$ ditolak jika

\subsection{Regresi Spasials}

Model umum regresi spasial dapat dituliskan sebagai berikut ${ }^{[11]}$ :

$$
\begin{aligned}
& \mathbf{y}=\rho \mathbf{W y}+\mathbf{X} \boldsymbol{\beta}+\mathbf{u} \\
& \mathbf{u}=\lambda \mathbf{W u}+\boldsymbol{\varepsilon}, \boldsymbol{\varepsilon} \square \mathbf{N}\left(0, \boldsymbol{\sigma}_{\varepsilon}^{2} \mathbf{I}_{n}\right)
\end{aligned}
$$

dengan: $\boldsymbol{y}=$ Vektor variabel dependen berukuran $\mathrm{n} \times 1$

$\rho \quad=$ Koefisien parameter spasial lag dari variabel dependen

$\boldsymbol{W} \quad=$ Matriks pembobot spasial yang berukuran $\mathrm{n} \times \mathrm{n}$

$\boldsymbol{X}=$ Matriks variabel independen berukuran $\mathrm{n} \mathrm{x}(\mathrm{k}+1)$

$\boldsymbol{\beta}=$ Vektor koefisien parameter regresi berukuran $(\mathrm{k}+1) \mathrm{x} 1$

$\lambda \quad=$ Koefisien parameter spasial error

$\mathbf{u}=$ Vektor error yang mempunyai efek spasial dengan ukuran nx1

$\boldsymbol{\varepsilon} \quad=$ Vektor error dengan ukuran $\mathrm{nx} 1$ 
Dari persamaan model umum regresi spasial (2), dapat dibentuk beberapa model lain sebagai berikut ${ }^{[1]}$ :

1. Jika $\rho=0$ dan $\lambda=0$ maka disebut model regresi linier klasik dengan persamaan yang terbentuk adalah:

$$
\mathbf{y}=\mathbf{X} \boldsymbol{\beta}+\boldsymbol{\varepsilon}
$$

2. Jika $\rho \neq 0$ dan $\lambda=0$ disebut regresi Spatial Autoregressive Model (SAR) dengan persamaan yang terbentuk adalah:

$$
\mathbf{y}=\rho \mathbf{W y}+\mathbf{X} \boldsymbol{\beta}+\boldsymbol{\varepsilon}
$$

3. Jika $\rho=0$ dan $\lambda \neq 0$ disebut regresi Spatial Error Model (SEM) dengan persamaan yang terbentuk adalah:

$$
\begin{aligned}
& \mathbf{y}=\mathbf{X} \boldsymbol{\beta}+\mathbf{u} \\
& \mathbf{u}=\lambda \mathbf{W u}+\boldsymbol{\varepsilon}
\end{aligned}
$$

4. Jika $\rho \neq 0$ dan $\lambda \neq 0$ disebut Spatial Autoregressive Moving Average (SARMA) dengan persamaan yang terbentuk adalah:

$$
\begin{aligned}
& \mathbf{y}=\rho \mathbf{W y}+\mathbf{X} \boldsymbol{\beta}+\mathbf{u} \\
& \mathbf{u}=\lambda \mathbf{W u}+\boldsymbol{\varepsilon}
\end{aligned}
$$

\subsection{Spatial Durbin Model (SDM)}

SpatialDurbin Model (SDM) merupakan model regresi spasial yang memiliki bentuk seperti Spatial Autoregressive Model (SAR) yang memiliki spasial lag pada variabel respon (Y) seperti pada persamaan (4). Hanya saja, SDM memiliki ciri khas adanya spasial lag pada variabel prediktor $(\mathbf{X})^{[1]}$. Model SDM memiliki bentuk persamaan sebagai berikut ${ }^{[12]}$ :

$$
\mathbf{y}=\rho \mathbf{W y}+\alpha \boldsymbol{1}_{n}+\mathbf{X} \boldsymbol{\beta}+\mathbf{W X} \boldsymbol{\theta}+\boldsymbol{\varepsilon}, \boldsymbol{\varepsilon} \square \mathbf{N}\left(0, \boldsymbol{\sigma}_{\varepsilon}^{2} \mathbf{I}_{n}\right)
$$

Atau dapat dituliskan sebagai berikut:

$$
\mathbf{y}=\rho \mathbf{W y}+\mathbf{Z} \boldsymbol{\delta}+\boldsymbol{\varepsilon}
$$

dengan: $\mathbf{Z}=\left[\begin{array}{lll}\mathbf{1}_{n} & \mathbf{X} & \mathbf{W X}\end{array}\right] ; \boldsymbol{\delta}=\left[\begin{array}{c}\alpha \\ \boldsymbol{\beta} \\ \boldsymbol{\theta}\end{array}\right]$

$\alpha \quad=$ Parameter konstan

$\boldsymbol{\theta} \quad=$ Vektor parameter lag spasial variabel prediktor berukuran $\mathrm{k} \times 1$

1n = Vektor yang berisi angka 1 berukuran $\mathrm{n} \times 1$

Parameter model SDM dapat diestimasi dengan menggunakan metode Maximum Likelihood Estimation (MLE), diperoleh estimasi parameter model SDM sebagai berikut:

$$
\begin{aligned}
& \frac{1}{\lambda_{\min }}<\rho<\frac{1}{\lambda_{\max }} \\
& \hat{\boldsymbol{\delta}}=\left(\mathbf{Z}^{\mathrm{T}} \mathbf{Z}\right)^{-1} \mathbf{Z}^{\mathrm{T}} \mathbf{y}-\hat{\rho}\left(\mathbf{Z}^{\mathrm{T}} \mathbf{Z}\right)^{-1} \mathbf{Z}^{\mathrm{T}} \mathbf{W} \mathbf{y}=\hat{\boldsymbol{\delta}}_{\mathbf{0}}-\hat{\rho} \hat{\boldsymbol{\delta}}_{\mathbf{d}} \\
& \hat{\sigma}^{2}=\frac{\left(\mathbf{e}_{\mathbf{0}}-\hat{\rho} \mathbf{e}_{\mathbf{d}}\right)^{\mathbf{T}}\left(\mathbf{e}_{\mathbf{0}}-\hat{\rho} \mathbf{e}_{\mathbf{d}}\right)}{n}
\end{aligned}
$$

\subsection{Pengujian Model Regresi}

\subsubsection{Uji Kecocokan Model}

Untuk menguji kecocokan model SDM digunakan prosedur uji dengan hipotesis sebagai berikut ${ }^{[15] \text { : }}$ 
$H_{0}: \rho=\beta_{j}=\theta_{j}=0$, dengan $\mathrm{j}=1,2, \ldots, \mathrm{k}$

$H_{1}: \rho \neq 0$ atau paling tidak ada satu $\beta_{j} \neq 0, \theta_{j} \neq 0$, dengan $\mathrm{j}=1,2, \ldots, \mathrm{k}$

Statistik Uji:

$$
F_{\text {hitung }}=\frac{S S_{R} / k}{S S_{E} /(n-k-1)}=\frac{M S R}{M S E}
$$

Keputusan: $\mathrm{H}_{0}$ ditolak jika nilai $F_{\text {hitung }}>F_{\alpha, k, n-k-1}$ atau $p$-value $<\alpha$

\subsubsection{Uji Signifikansi Parameter}

Pengujian signifikansi parameter pemodelan spasial menggunakan uji Wald ${ }^{[1]}$, untuk menguji parameter $\rho$ digunakan hipotesis sebagai berikut ${ }^{[15]}$ :

$$
H_{0}: \rho=0 ; H_{1}: \rho \neq 0
$$

Statistik Uji: Wald $_{\rho}=\frac{\hat{\rho}^{2}}{\operatorname{var}(\hat{\rho})}$

Untuk menguji parameter $\beta$ :

$$
H_{0}: \beta_{j}=0 ; \quad H_{1}: \beta_{j} \neq 0, j=1,2, \ldots, k
$$

Statistik Uji: Wald $_{\beta}=\frac{\hat{\beta}_{j}^{2}}{\operatorname{var}\left(\hat{\beta}_{j}\right)}$

Untuk parameter $\theta$ menggunakan hipotesis sebagai berikut:

$$
H_{0}: \theta_{j}=0 ; \quad H_{1}: \theta_{j} \neq 0, j=1,2, \ldots, k
$$

Statistik Uji: Wald $_{\theta}=\frac{\hat{\theta}_{j}^{2}}{\operatorname{var}\left(\hat{\theta}_{j}\right)}$

Kriteria pengambilan keputusan adalah $H_{0}$ ditolak jika nilai Wald $>\chi_{\alpha, 1}^{2}$.

\subsubsection{Uji Asumsi Regresi}

a. Uji Normalitas

Untuk menguji residual berdistribusi normal dapat digunakan uji KolmogorovSmirnov. Tahapan uji Kolmogorov-Smirnov sebagai berikut ${ }^{[5]}$ :

$\mathrm{H}_{0}$ : Residual berdistribusi normal

$\mathrm{H}_{1}$ : Residual tidak berdistribusi normal

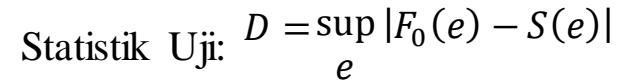

Kriteria uji: $\mathrm{H}_{0}$ ditolak jika $D \geq d_{(1-\alpha / 2)}$ atau $p$-value $<\alpha$

dengan $d_{(1-\alpha / 2)}$ adalah nilai kritis yang diperoleh dari tabel Kolmogorov-Smirnov.

\section{b. Uji Multikolinieritas}

Deteksi multikolinieritas bertujuan untuk menguji apakah dalam model regresi ditemukan adanya korelasi antar variabel prediktor. Salah satu cara untuk mengetahui adanya multikolinieritas dengan nilai Faktor Inflasi Varian (VIF), didefinisikan dengan rumus ${ }^{[13]}$ :

$$
\operatorname{VIF}\left(x_{j}\right)=\frac{1}{\left(1-R_{j}^{2}\right)}, \mathrm{i}=1,2, \ldots, \mathrm{n}
$$

Nilai $V I F>10$ menunjukkan multikolinearitas yang kuat ${ }^{[13]}$.

\section{c. Uji Autokorelasi}

Uji ini digunakan untuk mendeteksi data yang ada apakah terjadi autokorelasi atau tidak. Dengan menggunakan lambang : $E\left(\varepsilon_{i} \varepsilon_{j}\right)=0$ $i \neq j$ 
Salah satu cara untuk mendeteksi adanya autokorelasi dapat menggunakan metode DurbinWatso dengan hipotesis sebagai berikut:

$\mathrm{H}_{0}$ : Tidak ada autokorelasi positif atau negatif

$\mathrm{H}_{1}$ : Ada autokorelasi antar positif atau negatif

Statistik Uji: $d=\frac{\sum_{i=2}^{i=n}\left(e_{i}-e_{i-1}\right)^{2}}{\sum_{i=1}^{i=n} e_{i}^{2}}$

dengan:

$d \quad=$ nilai Durbin - Watson dari hasil perhitungan data

$e_{i} \quad=$ residual ke $\mathrm{i} \quad ; \quad e_{i-1} \quad=$ residual ke $\mathrm{i}-1$

d. Uji Heteroskedastisitas

Uji ini untuk melihat apakah variansi error satu pengamatan ke pengamatan yang lain konstan atau tidak. Lambang homoskedastisitas: $E\left(\varepsilon_{i}^{2}\right)=\sigma^{2} \quad i=1,2, \ldots, n$

Heteroskedastisitas dapat diperiksa dengan menggunakan uji Glejser ${ }^{[10]}$. Uji Glejser dilakukan dengan meregresikan nilai absolut residual $\left|e_{i}\right|$ terhadap variabel-variabel bebas yang diperkirakan mempunyai hubungan erat dengan $\sigma^{2}$.

$$
\left|e_{i}\right|=\beta_{0}+\beta_{1} x_{i 1}+\beta_{2} x_{i 2}+\cdots+\beta_{k} x_{i k}+v
$$

\subsection{Ukuran Kecocokan Model}

\section{a. Koefisien Determinasi $\left(R^{2}\right)$}

Koefisien determinasi $\left(R^{2}\right)$ dikenal untuk mengetahui proporsi variasi dalam y yang dapat dijelaskan oleh beberapa variabel $x$ secara bersama-sama (gabungan) ${ }^{[10]}$. Nilai $R^{2}$ terletak antara nol dan satu. Kecocokan model "lebih baik" jika $R^{2}$ semakin dekat dengan satu) ${ }^{[10]}$. Kebanyakan peneliti lebih suka menggunakan koefisien determinasi yang disesuaikan (Adjusted $\left.R^{2}\right)^{[14]}$, rumusnya sebagai berikut:

$$
R_{a d j, k}^{2}=1-\frac{S S_{E} /(n-k-1)}{S S_{T} /(n-1)}
$$

\section{b. $\quad$ Mean Square Error (MSE)}

Dalam analisis regresi, istilah Mean Square Error (MSE) digunakan untuk merujuk pada estimasi tak bias dari variansi error ${ }^{[13]}$. MSE diperoleh berdasarkan rumus ${ }^{[13]}$ :

$$
M S E=\frac{S S_{E}}{n-k-1}
$$

Jika nilai MSE semakin kecil hingga mendekati nol, dapat dikatakan bahwa model regresi semakin baik.

\subsection{Pencilan}

Pencilan adalah pengamatan yang tampak berbeda dengan pengamatan lainnya pada sekumpulan data yang ada ${ }^{[3]}$. Salah satu metode yang dapat digunakan untuk mendeteksi pencilan adalah Moran's Scatterplot yang merupakan salah satu metode yang dapat digunakan untuk mendeteksi adanya pencilan spasial[16]. Moran's Scatterplot merupakan grafik plot normal dengan nilai atribut $\left(z \mid f(i)=\frac{f(i)-\mu_{f}}{\sigma_{f}}\right)$ yaitu rata-rata nilai ketetanggaan dari nilai atribut yang telah dinormalisasi. Grafik dibagi menjadi empat kuadran, plot data yang berada di kuadran bagian kiri atas dan kanan bawah merupakan pencilan spasial.

Selain dilihat dari grafik, deteksi pencilan spasial menggunakan Moran's Scatterplot juga dapat diidentifikasi secara matematis menggunakan rumus:

$$
\left(Z[f(i)] x\left(\sum_{j}\left(\mathbf{W}_{i j} \mathbf{Z}[f(j)]\right)\right)\right)
$$


dengan $\mathbf{W}$ adalah matriks ketetanggaan, $Z_{i}=\frac{f(i)-\mu_{f}}{\sigma_{f}}, I_{i}=\left(\sum_{j}\left(\mathbf{W}_{i j} \mathbf{Z}[f(j)]\right)\right), \mu_{f}$ dan $\sigma_{f}$ adalah rata-rata dan standar deviasi dari fungsi f(i). Jika nilainya kurang dari 0 maka termasuk pencilan spasial, dan jika tidak maka sebaliknya.

\subsection{Regresi Robust}

Regresi robust adalah metode regresi yang digunakan ketika distribusi dari residual tidak normal atau ada beberapa pencilan yang mempengaruhi model ${ }^{[7]}$. Metode ini adalah alat yang penting untuk menganalisis data yang terkontaminasi oleh pencilan dan dapat memberikan hasil yang resisten akan kehadiran pencilan. Salah satu metode estimasi dalam regresi robust adalah Robust M-estimator.

\subsubsection{Robust M-Estimator}

Robust M-estimator sebenarnya meminimumkan fungsi obyektif ${ }^{[7]}$ :

$$
\min _{\beta} \sum_{i=1}^{n} \rho\left(u_{i}\right)=\min _{\beta} \sum_{i=1}^{n} \rho\left(\frac{e_{i}}{s}\right)=\min _{\beta} \sum_{i=1}^{n} \rho\left(\frac{y_{i}-\sum_{j=0}^{k} x_{i j} \beta_{j}}{s}\right)
$$

dengan $s$ adalah skala estimasi robust. Estimasi $s$ yang digunakan adalah:

$$
s=\frac{M A D}{0,6745}=\frac{\text { median } \mid e_{i}-\text { median }\left(e_{i}\right) \mid}{0,6745}
$$

Nilai 0,6745 menjadikan $s$ sebagai estimator tak bias dari $\sigma$ jika $n$ besar dan error berdistribusi norma[1]3].

Untuk mendapatkan estimasi parameter dengan meminimumkan persamaan (21). Dengan turunan parsial pertama dari $\rho$ terhadap $\beta_{j}(j=0,1, \ldots, k)$ disamakan dengan 0 , sehingga:

$$
\sum_{i=1}^{n} x_{i j} \psi\left(\frac{y_{i}-\sum_{j=0}^{k} x_{i j} \beta_{j}}{s}\right)=0, \quad j=0,1, \ldots, k
$$

Diberikan solusi dengan mendefinisikan fungsi pembobot:

$$
w\left(u_{i}\right)=\frac{\psi\left(\frac{y_{i}-\sum_{j=0}^{k} x_{i j} \beta_{j}}{s}\right)}{\left(\frac{y_{i}-\sum_{j=0}^{k} x_{i j} \beta_{j}}{s}\right)}
$$

dan $w_{i}=w\left(u_{i}\right)$. Kemudian estimasi persamaan (23) dapat ditulis:

$$
\sum_{i=1}^{n} x_{i j} w_{i}\left(y_{i}-\sum_{j=0}^{k} x_{i j} \beta_{j}\right)=0, \quad j=0,1, \ldots k
$$

Persamaan (25) diselesaikan dengan Iteratively Reweighted Least Square (IRLS). Pada notasi matriks, persamaan (25) dapat ditulis:

$$
\hat{\boldsymbol{\beta}}=\left(\mathbf{X}^{\mathbf{T}} \mathbf{W} \mathbf{X}\right)^{-1} \mathbf{X}^{\mathbf{T}} \mathbf{W} \mathbf{y}
$$

Iterasi akan berhenti jika $\hat{\beta}_{j}$ konvergen yaitu selisih nilai $\hat{\beta}_{j}^{(m+1)}$ dan $\hat{\beta}_{j}^{(m)}$ mendekati 0 .

\subsubsection{Fungsi Obyektif}

Fungsi yang digunakan untuk mencari fungsi pembobot pada regresi robust adalah fungsi obyektif $[8]$. Salah satu fungsi pembobot yang dapat digunakan adalah fungsi pembobot Tukey Bisquare sebagai berikut:

$$
w\left(u_{i}\right)=\left\{\begin{array}{cl}
{\left[1-\left(\frac{u_{i}}{c}\right)^{2}\right]^{2},} & \text { untuk }\left|u_{i}\right| \leq c \\
0 & , \text { untuk }\left|u_{i}\right|>c
\end{array}\right.
$$


Nilai c disebut tunning constant, dan tunning constant untuk fungsi pembobot Tukey Bisquare pada metode estimasi $M$-estimator adalah c $=4,685^{[8]}$.

\subsection{Angka Harapan Hidup}

Menurut Badan Pusat Statistik Indonesia, Angka Harapan Hidup (AHH) pada suatu umur $\mathrm{x}$ adalah rata-rata tahun hidup yang masih akan dijalani oleh seseorang yang telah berhasil mencapai umur x pada suatu tahun tertentu dan dalam situasi mortalitas yang berlaku di lingkungan masyarakatnya. Terdapat beberapa faktor yang berpengaruh signifikan terhadap AHH diantaranya adalah faktor pendidikan, faktor kesehatan dan faktor ekonomi. Variabel rata-rata lama sekolah digunakan sebagai variabel untuk menjelaskan faktor pendidikan. Variabel persentase rumah tangga berperilaku hidup bersih dan sehat dan jumlah posyandu digunakan sebagai variabel untuk menjelaskan faktor kesehatan. Variabel persentase penduduk miskin dan pengeluaran perkapita disesuaikan digunakan sebagai variabel untuk menjelaskan faktor ekonomi.

\section{METODOLOGI PENELITIAN}

\subsection{Sumber Data dan Variabel Penelitian}

Data yang digunakan dalam penelitian ini adalah data sekunder yang diperoleh dari katalog Provinsi Jawa Tengah Dalam Angka 2018 yang dikeluarkan oleh Badan Pusat Statistik (BPS) Provinsi Jawa Tengah dan buku Profil Kesehatan Provinsi Jawa Tengah Tahun 2017 yang dikeluarkan oleh Dinas Kesehatan Provinsi Jawa Tengah. Unit observasi dalam penelitian ini adalah 35 kabupaten dan kota di Provinsi Jawa Tengah. Variabel yang digunakan dalam penelitian ini adalah data $\mathrm{AHH}$ sebagai variabel respon dan rata-rata lama sekolah $\left(x_{1}\right)$, persentase rumah tangga berperilaku hidup bersih dan sehat $\left(x_{2}\right)$, jumlah posyandu $\left(x_{3}\right)$, persentase penduduk miskin $\left(x_{4}\right)$ dan pengeluaran perkapita disesuaikan $\left(x_{5}\right)$ sebagai variabel prediktor.

\subsection{Langkah-langkah Analisis}

Langkah-langkah analisis yang akan dilakukan pada penelitian ini sebagai berikut:

1. Mendapatkan data AHH beserta lima faktor yang diduga mempengaruhinya.

2. Menentukan matriks pembobot spasial berdasarkan queen contiguity.

3. Melakukan uji autokorelasi spasial dengan uji Moran's $I$.

4. Mengestimasi parameter dengan regresi Spatial Durbin Model.

5. Melakukan uji kecocokan model dan uji signifikansi parameter.

6. Menghitung koefisien determinasi yang disesuaikan (Adjusted $R^{2}$ ) dan MSE.

7. Melakukan uji asumsi pada model.

8. Melakukan pendeteksian pencilan dengan Moran's Scatterplot.

9. Mengestimasi parameter dengan regresi Robust Spatial Durbin Model M-estimator .

10. Melakukan uji kecocokan model dan uji signifikansi parameter.

11. Menghitung koefisien determinasi yang disesuaikan (Adjusted $R^{2}$ ) dan MSE.

12. Menentukan model regresi terbaik dan menganalisisnya.

\section{HASIL DAN PEMB AHASAN}

\subsection{Es timasi Parameter Regresi Robust Spatial Durbin Model}

Untuk memperoleh estimasi parameter model robust spatial durbin, maka dilakukan estimasi menggunakan metode kuadrat terkecil. Estimasi parameter dalam metode kuadrat terkecil dapat diperoleh dengan meminimumkan jumlah kuadrat residual sebagai berikut:

$$
\sum e_{i}^{2}=\sum\left[(\mathbf{I}-\rho \mathbf{W}) \mathbf{y}_{i}-\mathbf{Z}_{1} \boldsymbol{\delta}_{1 i}-\mathbf{Z}_{2} \boldsymbol{\delta}_{2 i}-\ldots-\mathbf{Z}_{k} \boldsymbol{\delta}_{k i}\right]^{2}=\mathbf{e}^{\mathbf{T}} \mathbf{e}
$$

sehingga diperoleh $\hat{\delta}_{\text {OLS }}=\left(\mathbf{Z}^{\mathbf{T}} \mathbf{Z}\right)^{-1} \mathbf{Z}^{\mathbf{T}}(\mathbf{I}-\rho \mathbf{W}) \mathbf{y}$

Untuk mendapatkan fungsi pengaruh, maka persamaan (28) dapat ditulis menjadi: 


$$
\hat{\boldsymbol{\delta}}_{\text {OLS }}=\left(\mathbf{Z}^{\mathbf{T}} \psi \mathbf{Z}\right)^{-1} \mathbf{Z}^{\mathbf{T}} \psi(\mathbf{I}-\rho \mathbf{W}) \mathbf{y}
$$

Dari fungsi pengaruh dapat didefinisikan fungsi pembobot $: b_{i}=b\left(u_{i}\right)=\frac{\psi\left(u_{i}\right)}{u_{i}}$ Maka dari itu dari persamaan (29) dapat ditulis:

$$
\hat{\boldsymbol{\delta}}_{\text {OLS }}=\left(\mathbf{Z}^{\mathrm{T}} \mathbf{B Z}\right)^{-1} \mathbf{Z}^{\mathrm{T}} \mathbf{B}(\mathbf{I}-\rho \mathbf{W}) \mathbf{y}
$$

dengan $\mathbf{B}$ adalah matriks pembobot yang berukuran $\mathrm{n} \times \mathrm{n}$ dengan elemen-elemen diagonal yang berisi pembobot $b_{1}, b_{2}, \ldots, b_{n}$.

\subsection{Uji Moran's I}

Diperoleh nilai Z-hitung beserta nilai Moran's I sebagai berikut:

Tabel 1. Uji Moran's I

\begin{tabular}{cccc}
\hline Variabel & Nilai Moran's $\boldsymbol{I}$ & Z-hitung & Kesimpulan \\
\hline $\boldsymbol{y}$ & 0,5752232 & 5,2978 & Tolak $\mathrm{H}_{0}$ \\
$\boldsymbol{x}_{\mathbf{1}}$ & 0,19489697 & 1,9503 & Terima $\mathrm{H}_{0}$ \\
$\boldsymbol{x}_{\mathbf{2}}$ & $-0,12105565$ & $-0,7779$ & Terima $\mathrm{H}_{0}$ \\
$\boldsymbol{x}_{\mathbf{3}}$ & 0,06377452 & 0,8069 & Terima $\mathrm{H}_{0}$ \\
$\boldsymbol{x}_{\mathbf{4}}$ & 0,35389376 & 3,2687 & Tolak $\mathrm{H}_{0}$ \\
$\boldsymbol{x}_{\mathbf{5}}$ & 0,17116800 & 1,7432 & Terima $\mathrm{H}_{0}$ \\
\hline
\end{tabular}

Dari Tabel 1 diperoleh hasil bahwa variabel y dan $x_{1}$ memiliki nilai $\left|Z_{\text {hitung }}\right|>1,96$, yang berarti $\mathrm{H}_{0}$ ditolak. Hal ini menunjukkan bahwa terdapat autokorelasi spasial antar lokasi pada variabel respon dan variabel prediktor. Karena pada variabel respon dan minimal satu dari variabel prediktor menunjukkan adanya autokorelasi spasial antar lokasi, maka model SDM dapat digunakan dalam penelitian.

\subsection{Regresi Spatial Durbin Model}

Model SDM yang diperoleh sebagai berikut:

$$
\begin{aligned}
\hat{y}_{i}= & 0,63839 \sum_{j=1}^{n} w_{i j} y_{j}+23,70977+0,61799 x_{i 1}+0,02843 x_{i 2}-2,6744 x 10^{-6} x_{i 3} \\
& -0,19592 x_{i 4}-2,6278 x 10^{-4} x_{i 5}-0,84814 \sum_{j=1}^{n} w_{i j} x_{j 1}-0,01467 \sum_{j=1}^{n} w_{i j} x_{j 2} \\
& +0,00138 \sum_{j=1}^{n} w_{i j} x_{j 3}+0,11522 \sum_{j=1}^{n} w_{i j} x_{j 4}+6,111 \times 10^{-4} \sum_{j=1}^{n} w_{i j} x_{j 5}
\end{aligned}
$$

\subsubsection{Uji Hipotes is}

\section{- Uji Kecocokan Model Regresi SDM}

Berdasarkan hasil komputasi dengan menggunakan software $R$, diperoleh nilai $\mathrm{F}_{\text {hitung }}$ $=8,7936$ dimana nilai tersebut lebih besar dari $\mathrm{F}_{\text {tabel }}=2,49$. Kemudian diperoleh nilai $p$ value sebesar $0,0000<\alpha=5 \%$. Sehingga diperoleh keputusan bahwa $\mathrm{H}_{0}$ ditolak pada taraf signifikansi 5\%. Jadi, dapat disimpulkan bahwa model SDM telah sesuai untuk menggambarkan hubungan antara variabel respon dan variabel prediktor.

\section{- Uji Signifikansi Parameter Model SDM}

Dapat dilihat bahwa parameter lag spasial $(\rho)$ dan parameter $\beta_{4}$ berpengaruh signifikan terhadap model karena nilai wald yang diperoleh $>\chi_{0,05,1}^{2}=3,841$, sedangkan parameter $\beta_{1}, \beta_{2}, \beta_{3}, \beta_{5}, \theta_{1}, \theta_{2}, \theta_{3}, \theta_{4}$ dan $\theta_{5}$ tidak berpengaruh signifikan terhadap model karena nilai wald yang diperoleh $<\chi_{0,05,1}^{2}=3,841$. 
Tabel 2. Uji Signifikansi Parameter SDM

\begin{tabular}{cccccc}
\hline Parameter & Wald & Keputusan & Parameter & Wald & Keputusan \\
\hline Rho & 5,59767 & $\mathrm{H}_{0}$ ditolak & $\beta_{5}$ & 1,44171 & $\mathrm{H}_{0}$ diterima \\
Intercept & 1,80201 & $\mathrm{H}_{0}$ diterima & $\theta_{1}$ & 0,70375 & $\mathrm{H}_{0}$ diterima \\
$\beta_{1}$ & 2,84664 & $\mathrm{H}_{0}$ diterima & $\theta_{2}$ & 0,07086 & $\mathrm{H}_{0}$ diterima \\
$\beta_{2}$ & 1,32565 & $\mathrm{H}_{0}$ diterima & $\theta_{3}$ & 1,38198 & $\mathrm{H}_{0}$ diterima \\
$\beta_{3}$ & $2,868 \times 10^{-5}$ & $\mathrm{H}_{0}$ diterima & $\theta_{4}$ & 0,4234 & $\mathrm{H}_{0}$ diterima \\
$\beta_{4}$ & 7,05707 & $\mathrm{H}_{0}$ ditolak & $\theta_{5}$ & 1,54393 & $\mathrm{H}_{0}$ diterima \\
\hline
\end{tabular}

\subsubsection{Ukuran Kecocokan Model \\ a. Adjusted R $\mathbf{R}^{\mathbf{2}}$ \\ $R^{2}{ }_{\text {Adj }, k}=0,6963$}

Artinya angka harapan hidup dipengaruhi oleh rata-rata lama sekolah, persentase rumah tangga berperilaku hidup bersih dan sehat, jumlah posyandu, persentase penduduk miskin dan pengeluaran per kapita disesuaikan sebanyak 69,63\% dan sisanya sebanyak 30,37\% dipengaruhi oleh faktor yang lain.

b. MSE

MSE $=1,15641$

\subsubsection{Uji Asumsi Model}

\section{- Asumsi Normalitas}

Berdasarkan hasil komputasi dengan menggunakan software $R$, diperoleh nilai hitung $\mathrm{D}=0,16089$ < nilai tabel $\mathrm{d}=0,224$ yang diperoleh dari tabel Kolmogorov-Smirnov dan nilai probabilitas yang didapat adalah sebesar 0,2928 $>\alpha=0,05$ yang menunjukkan bahwa $\mathrm{H}_{0}$ diterima atau residual model berdistribusi normal.

\section{- $\quad$ Asumsi Multikolinie ritas}

Berdasarkan hasil komputasi dengan menggunakan software $R$, diperoleh hasil yaitu nilai $\operatorname{VIF}\left(x_{1}\right)=5,78165, \operatorname{VIF}\left(x_{2}\right)=1,71299, \operatorname{VIF}\left(x_{3}\right)=1,86858, \operatorname{VIF}\left(x_{4}\right)=2,3402, \mathrm{VIF}$ $\left(x_{5}\right)=4,05949, \operatorname{VIF}\left(x_{6}\right)=7,59969, \operatorname{VIF}\left(x_{7}\right)=2,46578, \operatorname{VIF}\left(x_{8}\right)=2,39775, \operatorname{VIF}\left(x_{9}\right)=$ 5,1459 serta VIF $\left(x_{10}\right)=4,89374$. Dapat dilihat bahwa nilai VIF $<10$ pada semua variabel prediktor, maka dapat disimpulkan tidak terjadi multikolinieritas pada variabel prediktor.

\section{- $\quad$ Asumsi Non - Autokore lasi}

Berdasarkan hasil komputasi dengan menggunakan software $R$, diperoleh nilai hitung $\mathrm{d}=2,252943$. Nilai 4- $\mathrm{d}_{\mathrm{U}}$ sebesar 2,1971 dan nilai 4- $\mathrm{d}_{\mathrm{L}}$ sebesar 2,8399. Dapat dilihat bahwa nilai $4-\mathrm{d}_{\mathrm{U}}=2,1971<\mathrm{d}<4-\mathrm{d}_{\mathrm{L}}=2,8399$ yang menunjukkan bahwa tidak ada keputusan.

\section{- Asumsi Homoskedastisitas}

Berdasarkan hasil komputasi dengan menggunakan software $R$, diperoleh hasil yaitu nilai Prob $\left(x_{1}\right)=0,90241$, Prob $\left(x_{2}\right)=0,21038$, Prob $\left(x_{3}\right)=0,23907$, Prob $\left(x_{4}\right)=0,11063$, Prob $\left(x_{5}\right)=0,36929$, Prob $\left(x_{6}\right)=0,49575$, Prob $\left(x_{7}\right)=0,45537$, Prob $\left(x_{8}\right)=0,18547$, Prob $\left(x_{9}\right)=0,21109$ serta Prob $\left(x_{10}\right)=0,28783$. Hasil pengujian menunjukkan bahwa semua variabel prediktor tidak signifikan pada tingkat signifikansi 5\%, karena semua nilai probabilitasnya $>\alpha=0,05$. Sehingga dapat disimpulkan bahwa tidak terjadi kasus heteroskedastisitas pada model SDM dengan 5 variabel prediktor. 


\subsection{Plot Residual}

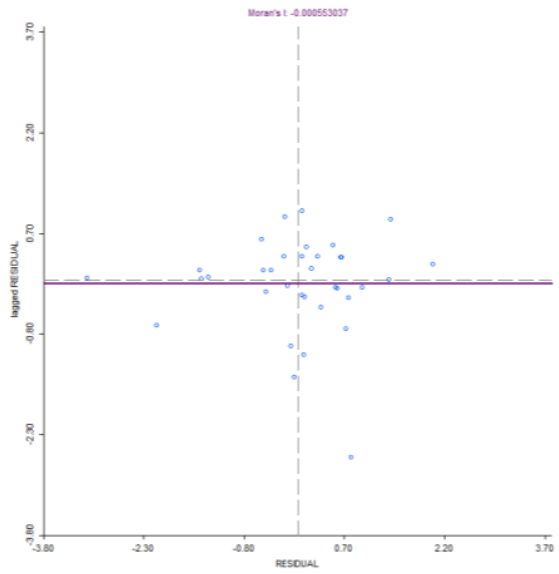

Gambar 1. Plot Residual

Pada Gambar 1, secara visual terdapat beberapa pencilan spasial dalam data residual. Untuk memastikan data mana saja yang termasuk pencilan, maka dilakukan deteksi pencilan secara formal dengan rumus $\left(Z[f(i)] x\left(\sum_{j}\left(\mathbf{W}_{i j} \mathbf{Z}[f(j)]\right)\right)\right)<0$.

\subsection{Pendeteksian Pencilan}

Dari hasil output, dapat diketahui bahwa ada sebanyak 19 pencilan spasial terdeteksi, yaitu wilayah ke 1, 2, 9, 10, 11, 14, 16, 17, 18, 20, 23, 24, 27, 29, 30, 31, 32, 33 dan 34.

\subsection{Regresi Robust}

\subsubsection{Regresi Robust M-Estimator}

Model regresi robust M-estimator dengan pembobot Tukey Bisquare yang didapatkan setelah proses 18 kali iterasi adalah sebagai berikut :

$$
\begin{aligned}
\hat{y}_{i}= & 0,63839 \sum_{j=1}^{n} w_{i j} y_{j}+28,76139+0,67309 x_{i 1}+0,03036 x_{i 2}+0,00045 x_{i 3} \\
& -0,11198 x_{i 4}-0,00025 x_{i 5}-1,70228 \sum_{j=1}^{n} w_{i j} x_{j 1}+0,05127 \sum_{j=1}^{n} w_{i j} x_{j 2} \\
& +0,00214 \sum_{j=1}^{n} w_{i j} x_{j 3}-0,09736 \sum_{j=1}^{n} w_{i j} x_{j 4}+0,00025 \sum_{j=1}^{n} w_{i j} x_{j 5}
\end{aligned}
$$

\subsection{Pemilihan Model Regresi Terbaik}

Tabel 3. Perbandingan Regresi SDM dan Regresi Robust SDM

\begin{tabular}{ccc}
\hline & Adjusted $\boldsymbol{R}^{\mathbf{2}}$ & MSE \\
\hline Regresi SDM & 0,6963 & 1,15641 \\
Regresi Robust SDM & 0,9369 & 0,12551 \\
\hline
\end{tabular}

Kriteria pemilihan model regresi terbaik yaitu mempunyai $R^{2}{ }_{A d j, k}$ terbesar dan nilai MSE terkecil. Diperoleh hasil bahwa model robust SDM memiliki nilai Adjusted $R^{2}$ lebih besar yaitu sebesar 0,9369 dan nilai MSE yang lebih kecil yaitu sebesar 0,12551. Maka dari itu dapat disimpulkan bahwa model robust SDM lebih baik daripada model SDM.

\section{KESIMPULAN}

Berdasarkan hasil dan pembahasan yang telah dilakukan, maka dapat ditarik beberapa kesimpulan sebagai berikut:

1. Model regresi spasial terbaik yang diperoleh adalah 


$$
\begin{aligned}
\hat{y}_{i}= & 0,63839 \sum_{j=1}^{n} w_{i j} y_{j}+28,76139+0,67309 x_{i 1}+0,03036 x_{i 2}+0,00045 x_{i 3} \\
& -0,11198 x_{i 4}-0,00025 x_{i 5}-1,70228 \sum_{j=1}^{n} w_{i j} x_{j 1}+0,05127 \sum_{j=1}^{n} w_{i j} x_{j 2} \\
& +0,00214 \sum_{j=1}^{n} w_{i j} x_{j 3}-0,09736 \sum_{j=1}^{n} w_{i j} x_{j 4}+0,00025 \sum_{j=1}^{n} w_{i j} x_{j 5}
\end{aligned}
$$

Model yang lebih baik digunakan untuk menjelaskan angka harapan hidup di Provinsi Jawa Tengah tahun 2017 adalah model robust spatial durbin, karena nilai Adjusted $R^{2}$ yang diperoleh lebih besar dan nilai MSE yang diperoleh lebih kecil.

2. Faktor-faktor yang berpengaruh signifikan terhadap angka harapan hidup di Provinsi Jawa Tengah pada tahun 2017 adalah rata-rata lama sekolah, persentase rumah tangga berperilaku hidup bersih dan sehat, jumlah posyandu, persentase penduduk miskin dan pengeluaran per kapita disesuaikan.

\section{DAFTAR PUSTAKA}

[1] Anselin, L. 1988. Spatial Econometrics: Methods and Models. Dordrecht: Kluwer Academic Publishers.

[2] Badan Pusat Statistik (BPS). 2018. Jawa Tengah Dalam Angka 2018. Semarang: Badan Pusat Statistik Jawa Tengah.

[3] Barnett, V., dan Lewis, T. 1994. Outliers in Statistical Data (3rd ed.). New York: John Wiley and Sons, Inc.

[4] Chen, C. 2002. Robust Regression and Outlier Detection with The ROBUSTREG Procedure, pp 265-27. SAS Institute Inc., Lary, NC.

[5] Conover, W. J. 1980. Practical Nonparametric Statistics (2nd ed). New York: John Wiley and Sons, Inc.

[6] Dinas Kesehatan. 2018. Profil Kesehatan Provinsi Jawa Tengah Tahun 2017. Semarang: Dinas Kesehatan Provinsi Jawa Tengah.

[7] Draper, N. R., dan Smith, H. 1998. Applied Regression Analysis (3rd ed.). New York: John Wiley and Sons.

[8] Fox, J. 2002. Robust Regression : Appendix to An R and S-Plus Companion to Applied Regression.

[9] Goodchild, M. F. 1986. Spatial Autocorrelation. Norwich: Geo Books.

[10] Gujarati, D. N. 2004. Basic Econometrics 4th Edition. New York: The McGraw-Hill Companies.

[11] LeSage, J. P. 1999. The Theory and Practice of Spatial Econometrics. Ohio: Department of Economics, University of Toledo.

[12] LeSage, J., dan Pace, R. K. 2009. Introduction to Spatial Econometrics. New York: Taylor \& Francis Group.

[13] Montgomery, D. C., dan Peck, E. A. 1992. Introduction To Linier Regression Analysis. New York: John Wiley and Sons, Inc.

[14] Montgomery, D. C., dan Runger, G. C. 2003. Applied Statistics and Probability for Engineers. New York: John Wiley \& Sons, Inc.

[15] Ramadani, I. R., Rahmawati, R., Hoyyi, A. 2013. "Analisis Faktor-faktor yang Mempengaruhi Gizi Buruk Balita di Jawa Tengah Dengan Metode Spatial Durbin Model”. Jurnal Gaussian. Vol. 2, No. 4 : Hal. 333-342. Universitas Diponegoro, Semarang.

[16] Shekhar, S., Lu, C. T., and Zhang, P. 2003. "A Unified Approach to Detecting Spatial Outliers". GeoInformatica 7:2, pp. 139-166.

[17]Wuryandari, T., Hoyyi, A., Kusumawardani, D., Rahmawati, D. 2014. "Identifikasi Autokorelasi Spasial Pada Jumlah Pengangguran di Jawa Tengah Menggunakan Indeks Moran”. Jurnal Media Statistika. Vol. 7, No. 1 : Hal. 1-10. Universitas Diponegoro. 